\title{
Possible EfFects of Spatial Injustice on the Sense of Belonging OF BlaCK COMMUNities' in SOUTH AFRiCAN Metros: A ReView OF Literature
}

\author{
${ }^{* 1}$ F. T Khaile, ${ }^{2}$ N.V. Roman, ${ }^{1}$ G. J Davids \\ ${ }^{1}$ School of Government, Faculty of Economic and Management Sciences, University of the Western Cape, \\ Private Bag X17, Bellville, email fkhaile@uwc.ac.za ; gjdavids@uwc.ac.za. \\ ${ }^{2}$ Centre for Interdisciplinary Studies of Children, Families and Society, Faculty of Community and Health \\ Sciences, University of the Western Cape, Private Bag X17, Bellville email: nroman@uwc.ac.za.
}

\begin{abstract}
Globally, a sense of belonging is gaining significant traction within the migration and urbanisation discourse. In South Africa, a sense of belonging is also introduced as a possible contribution to social cohesion and ultimately nation-building. However, indications are that the entrenched and pervasive spatial injustice is impacting negatively on efforts to achieve a sense of belonging for black communities to their metros. This paper highlights the possible effects of spatial injustice to the development of a sense of belonging of black communities to their metros. Utilising literature, the paper highlights the lack of spatial injustice as contributing towards frustrating diversity and place of attachment. Equally, the paper identified four themes such as fractured social relations, limited citizenship, lack of social capital and erosion of trust as some of the possible effects of spatial injustice on the development of a sense of belonging in metros.
\end{abstract}

Key words: spatial injustice, sense of belonging, metros, urban, municipalities, communities.

DOI: $10.7176 / \mathrm{JCSD} / 62-05$

Publication date:October $31^{\text {st }} 2020$

\section{INTRODUCTION}

The reality of the untransformed socio-spatial division and dynamics of South Africa continues to produce disturbing social injustice in communities. Various authors have highlighted that municipalities have failed to overcome historical exclusions and divisions as reinforced by apartheid spatial divide and its related urban geography (Marcuse, 2009;Soja, 2009; Van Wyk, 2015; David, Leibbrandt and Shifa,2018; Turok, 2018). Equally, literature indicates that the persistent apartheid spatial divide and its related urban geography have resulted in pervasive spatial fragmentation; exacerbated social polarisation, weak social relations, conflict, mistrust and marginalisation (Pieterse, 2009; Kiguwa and Langa, 2015;SALGA, 2016). Therefore, the constitutionally envisioned ideals of society reflecting collective identity, recognition and belonging have remained disappointingly elusive.

Evidently, for black people who were and are still largely outside or in the periphery of metros, continue to lack a sense of belonging to these municipalities (South African Cities Network; Johannesburg Development Agency, 2014). Moegoeng (2016) emphasises this assertion when stating that, very little recognition has been given to black people and their sense of belonging has been denied (City of Tshwane Metropolitan Municipality v Afriforum). Equally, Carolissen and Kiguwa (2018) lament that "despite being legitimate in spaces, blacks in many respect continue to experience their belonging as conditional, contingent, marginal and circumscribed by the other".

In terms of the above, it is therefore inconceivable to expect black communities to have a sense of belonging to spaces characterised by pervasive spatial injustice. It is thus widely recognised, albeit anecdotal that the injustice procreated by the untransformed spatial divide is negatively impact on black communities' sense of belonging to metros. Literature has not paid adequate attention to the relationship between spatial injustice and lack of sense of belonging for black communities towards the metros. It has therefore remained unclear how spatial injustice contribute towards lack of belonging in cities or metros in South Africa. This literature review helps to explore this relationship in order to develop an understanding of the issues impacting the development of cohesive South African society. 
The question being explored in this paper is what are the possible effects of spatial injustice on black communities' sense of belonging in metro as urban municipalities? The objective is to contribute to the debates on the conceptual linkages between spatiality and belonging and specifically, explore the possible effects of spatial injustice to the highlighted lack of sense of belonging by black communities to their metros. To realise this objective, the paper first discusses the concept of spatial justice as an aspect of social justice. Situating belonging at the centre of sociospatial justice is critical in understanding underlying factors ad dynamics that either promote or undermine a sense of belonging. Secondly, the paper explores the relationship between spatial injustice and how it contributes to the lack of belonging in South African metros. The paper concludes by highlighting possible effects of spatial injustice on the black communities' sense of belonging to metros in South Africa.

\section{The Pursuit of Spatial Justice}

Spatial organisation is gradually becoming one of the critical area of justice, development and sustainable environment. Hence, the relationship between justice and place has been a recurring aspect of the discourse on urban geography and planning. Equally, the issue of justice has been raised in the field of geography from time to time with regard to globalisation, suburbanisation, gentrification and immigration processes (Israel \& Frenkel, 2018). In this regard, exploring spatiality within the context of justice strengthens a theoretical understanding that is useful in making explicit the link between spatial and social.

Spatiality is a commonly understood as a combination of space and place. Seamon and Sowers (2008) note that many geographers relate to the concepts of space and place as separate even though they are both essentially about the "where". Likewise, Koops and Galic (2017) refer to space and place as being intrinsically related concepts constituting each other. Thus, to avoid possible confusion, it is necessary to provide clarity between the concepts of space and place. Koops and Galic (2017: 23) also argue that "one important contribution from geography is a more precise meaning of each of these terms.

Within a geographic context, pace is usually defined as physical entity where where something or somebody is located or an area where people dwell together Ujang and Zakariya (2015; Soja 2016). For instance, space is about human existence in a town; municipality; street and home. Soja (2016) adds that space is about social landscape. Soja's assertion resonates well with (Kitchin, 1998) observation that space is not just a passive container of life, but also as an active constituent of social relations cable of being politically, economically and socially being claimed and contested. Neely and Samura (2011: 1938) describe the central characteristics of space as "contested, fluid and historical relational and interactional and infused with difference and inequality".

On the other hand, (Saar \& Palang, 2009) define place as a socially contrasted to facilitate interaction between people and groups. Place is about people relationship with space. Meaning that, when space as a physical entity is imbued with meaning in everyday place-bound social practice, it changes to place (Ujang and Zakariya, 2015). (Withers, 2009) asserts that the sense of place is taken to embrace the affective attachment that people have with it and become the centre of their existence. Importantly, place is an experience and ability to identify with the space. Therefore, the space and place nexus is about a physical territory or jurisdiction that can be seen and touched while place is space infused with human meaning. Both are essential in forming a part of a human spatial experience as it is a lived as indivisible whole.

The logical question that follows is what the relationship between spatiality and justice is. Understandably, the human element of spatiality has brought the fore the issue of justice. Justice in the context of spatiality is concerned with the eradication of poverty and inequalities and facilitating access to material resources that enable equal to participate in socio-political life of a society (Huffman (2014: 3). Therefore, spatial justice is about institutions, policies, discourse and practice involved in formulating the organisation of space, thus shaping human interactions that define (un)just geographies" (Soja, 2010:15). (Dikeç, 2001) describes the "notion of spatial justice as a critique of systematic exclusion, domination and oppression in a manner that cultivates new sensibilities that would animate actions towards injustice embedded in space and spatial dynamics".

As a complex social product, spatial justice is collectively created and purposeful configured socialisation of space. Bromberg, Marrow and Pfeiffer (2007: 2) explains the relationship between spatiality and justice as "a socially produced, experienced and contested and constantly shifting social, political, economic and geographical terrains, means that justice - if it is concretely achieved, experienced and reproduced-must be engaged on spatial as well as social terms".

Likewise, (Charman, Tonkin, Denoon-stevens, \& Demeestére, 2017) presents spatial justice as a focused and deliberate emphasis on the spatial or geographical aspects of justice. It is described as process determining how 
human societies organise spaces which reflect how justice played out. It is also considered to humanise the geography in which people live their lives. Most importantly, spatial justice contributes toward the promotion of equality, freedom, human rights, distribution, fairness, participation, inclusion, democracy, power (Griffiths, 2003; Sandel, 2009). Therefore, it focuses on who gets what within the same space.

In terms of the above, prevailing geographical, sociological, political and cultural interactions between individuals and groups provide an indication of just or unjust society. Specifically, spaces that do not facilities just, equal and fair distribution are considered to be promoting spatial injustice. Spatial injustice, according to Israel and Frenkel (2018: 650), refer to formalising an unjust social arrangement in a manner that "conceals the asymmetry of power relations in cultural, gender, race and class cleavages". Similarly, Dikec (2001: 1792) argues that "injustice is largely socially and spatially manifested and it is produced not only socially but spatially as well. Hence, De Beer (2016) argues that there is link between social (in)justice and spatiality in a sense that space and places are constructed socially and politically to produced intended social in(justice). Arguably, justice or injustice in a space is not natural phenomena but consciously created by society. It is accordingly logical to concede that just as space influences the formation of a society, equally, society creates (in)justice through space.

In the South African context, the aspiration of nation building necessitated a conscious effort to eliminate injustices from the South African society. Thus, the need to address the injustices is well recognised by the preamble of the Constitution of the Republic of South Africa, 1996 ("the Constitution"). According to (Fuo, 2013), there is a firm constitutional commitment to pursue social justice as a means of eradicating poverty and extreme inequalities. Similarly, Chaskalson (2000 argues that the constitutional commitment for social justice obligates government to ensure that the basic needs of all people and promote an environment in which people live together in harmony, showing respect and concern for one another. Implicit in the Constitution therefore, is the creation of a just society characterised by social arrangement in which South African citizens coexist mutually and peacefully. Thus, the pursuit of social justice is aimed at the realisation of liveable and integrated communities to ensure a decisive break from the apartheid past that intentionally promoted exclusion, unequal, unevenly polarised and divided communities

However, after twenty-five years, South African cities are still characterised by spatial arrangements in which white population reside in well-located city cores, while the black population exist in the racialised excluded margins of the cities (Turok, 2016). Equally, Mandell in Western Cape Environmental and Developmental Planning (2016), states that the current spatial planning practice have reinforce the apartheid city. Undeniably, the current spatial arrangements continue to reflect the exclusionary political ideology of apartheid. This provides evidence that spatial arrangements are not neutral and decontextualized spaces, but reflect a deliberate political engineered of space. According to Mathebula (2018: 260) "the erstwhile policies of apartheid dispensation where particular segments of the population were coerced to reside in certain areas without their consent".

Evidently, spatial injustice in South Africa is an undeniable reality. There is an observable unanimity among authors that the persistent spatial legacy of apartheid remains visible and untransformed. Quite notably, the failed spatial transformation has exacerbated pervasive inequality, which in turn divides rather than unites communities in us and them" (South African Cities Network, 2016; South African Local Government Association, (SALGA) (2017; Von Fintel, 2018). Similarly, authors such as Dikec (2001) Soja (2010) Clearly, the untransformed spatial patterns have ritualised the organisation of space in metros on the bases of racial segregation.

The South African Cities Network (2016) attributes social vulnerability that has condemned people in the distinct peripheral spatial location such as informal settlements or in townships, to spatial injustice. Iveson (2011) are emphatic that social injustices have a spatial aspect that in various forms of injustice which include the process of spatialization. Equally, the South African Cities Network (2016) acknowledges that spatial injustice has affected the ability to address socioeconomic inequality. Thus, South African cities continue to reflect high levels of polarisation. In particular, the persistent patterns of spatial injustice continue to reproduce poverty and inequality.

In addition, Burger, Van der Berg, Van der Walt and Yu and 2017: 6) lament that "spatial injustice has reproduced inequality that remains strongly correlated with race". Similarly, the South African Network (2016: 48) highlights that in cities, economic and social inequities manifest in embedded spatial imbalances, labour living far from work, suffering long and expensive commutes; racially and class-distinct neighbourhoods; black peripheries and inner cities characterised by poor and informal housing and environments; economies that follow historical patterns and are concentrated far from the poor majority. In response to these imbalances, the mantra has been "spatial transformation". 
Needless to say that the prevailing spatial injustice has perpetuated intentional spatial and social distance between the white and black communities in metros. The South African Cities Network (2016: 154) highlights that South African cities are experiencing the type of pressure that can only lead towards deeper socio-spatial division, with poor, black families having no voice to engage authorities in respect of their most basic needs. Fundamentally, metros have not only failed to put an end to socio-spatial exclusion based on race but inadvertently legitimised some form of spatial exclusion. Accordingly, there is a visible weak social interaction, lack of solidarity, conflict, mistrust, marginalisation, lack recognition and acceptance between black and white communities, even though they inhabit in the same metro (Kiguwa and Langa, 2015). Undoubtedly, the pervasive spatial injustice has also heightened contestations for space between the white and black communities. White communities have openly embraced the spatial distance and displacement of black communities from the urban core, while black communities are confronting exclusion and marginalisation to the periphery of the urban margins.

\section{FAiled SPATIAL TRANSFORMATION}

South Africa's constitutional transformative agenda embarked upon since 1996 instigated great anticipation for transformation of apartheid urban spatial pattern. The need for spatial transformation was informed by an understanding that communities in South Africa were (and are still) characterised by racial inequality, marginalisation and unjust distribution of resource. The increasing levels of marginalisation and marginalisation of black communities has been widely identified as unjust and requiring transformation. There is also an understanding that the current destructive spatial arrangement is not natural by conscious constructions designed to exclude black communities from the social-economic infrastructure of metros. The obviously high level of inequality is the constant reminder to black communities of the injustice to their space.

In terms of the above, it was acknowledged that urban municipalities, especially cities/metros established in a new constitutional dispensation have inherited an enormous legacy of unrelenting spatial inequality. Accordingly, it was envisaged that metros would develop the rhythms and the fabric of South African cities to be radically transformed in order to foster justice for black communities (Dirsuweit, 2009). According to (Pieterse, 2019), the focus on of urban spatial transformation was largely because the redistributive ambitions of the newly elected government invariably had to involve some form of urban justice and rebalancing as this was where the heart of economic apartheid resided.

Though it is ultimately the responsibility of the government as whole to address, metros as large cities, were envisaged to play a significant role in addressing social injustice perpetuated through spatial injustice. There is a consistent inference in the literature is that municipalities have a critical role in promoting social justice in order to address the practice of exclusion (Turok, 2016). Explicitly, section 152 (1) (c) of the Constitution Act 108 of 1996, bequeaths municipalities with a developmental objective of promoting social and economic development of communities. According to (Visser, 2001), it was anticipated that the pursuit of social justice by municipalities will serves as the bedrock of democratic South Africa in which citizens can actively participate in a free, tolerant and inclusive political community. Various authors indicate that metros are appropriate government entity capable of driving the pursuit of social justice (Langa, 2005; De Visser, 2009; Fuo, 2013; Fuo, 2014).

Therefore, metros are constituted as legal, socio-political structures considered appropriate to mediate highly contested politicised socio-economic processes. Notably, the Local Government White Paper of 1998 recognises that a more equitable and socially just form of metropolitan governance was essential to address inequity between constituent parts of a metro area". In addition, metros as municipality governing major cities in South Africa were expected to transform the persistent spatial fragmentation and related inequality dating from for the colonial and apartheid past. In the matter between the City of Tshwane Metro and Afriforum, Mogoeng CJ, aptly refers to municipalities as being constitutionally endowed with the duty to transform their areas from racist, undemocratic, ethnic and tribal divisions and exclusions that characterised those prior 1994 (City of Tshwane Metropolitan Municipality v Afriforum and Another, 2016).

However, literature is unanimous that spatiality in South Africa remains untransformed. The National Planning Commission (2011); South African Cities Network (2016) are adamant that spatial patterns have not only remained unchanged but have also reproduced themselves. Thus,

according to the current systems and processes often reinforce an unequal and unjust status quo (South African Cities Network (2016). Thus, the inability of metros to address spatial challenges and dynamics have had negative effects on these municipalities to realise constitutional ideals of equity, prosperity and sustainability, at least for the black majority. Arguably, the resultant displacement, marginalisation, inadequate shelter, and poor access to the socioeconomic opportunities by black communities has reinforced spatial injustice. 
Quite evident is that the current spatial injustice exacerbated inclusion and disinvestment in black communities. In addition, both black and white communities continue to exist in spaces that entrench racialisation of these spaces hence sections of the metros consist of homogeneous racial and ethnic groups and identities. In this regard, spatial configurations that have constructed an intersection at which race-space connect. Brooke and Samura (2011: 1940) quoting Knowles (2003) articulate this interaction as follow:

"Space is an active archive of the social process and social relationships composing racial orders. Active because it is not just a monument, accumulated through a racial past and present -although it is also that-it is active in the sense that it interacts with people and their activities as an ongoing set of possibilities in which race is fabricated".

\section{SENSE OF BELONGING}

The notion of belonging has recently emerged as a critical issue confronting society (Yuval-Davis, 2015). Along with concepts such as inclusivity, social solidarity, social cohesion, belonging has featured prominently in debates about identity, citizenship and migration. Youkhana (2015) suggests that the concept of belonging has gained significant traction from multiple disciplines including political science, psychology and sociology (Yuval-Davis, 2011). Consequently, the diverse exploration of the concept by various disciplines has inevitably led to it being multidimensional, vaguely defined and under-theorised (Yuval-Davis, 2011; Youkhana, 2015). Hence, Antonsich (2010) Yuval-Davis (2011) conclude that there is a difficulty in defining the concept of belonging and contestations are bound to avoid veering into an elaborate exploration of the available definitions of belonging, this paper decidedly confines itself to two definitions that are appropriately broad enough to accommodate pertinent issues raised in this paper. Firstly, Hill (2006:1) defines belonging as "relatedness and connectedness to someone or something". Secondly, Yuval-Davis (2011: 200) defines belonging as a "state of emotion and mind which is critical to people's emotional balance and well-being in a context of normative differences constructed in different public, formal and informal discourses".

The concept of a sense of belong is considered broad and used interchangeably with concept such as rootedness and a sense of place (Ujang and Zakariya, 2015). While it is acknowledged that the concept of belonging is problematically broad, there is however, less disagreement that, belonging is a human need that promotes a relationship, ability to shape identity, recognition, acceptance and attachment with someone or something. Other authors such as Kamenov (2003) regard belonging highly to the extent that are not surprised that "Maslow postulated the need for belonging as the basic human need". The significance of belonging to human beings is such that, its absence has the potential to produce pathological and long-lasting negative consequences such as emotional distress (Anderman, 2002). To the contrary, it often accepted that a sense of belonging promotes feelings of inclusion, relatedness, connectedness and collectivism.

In the context of space and place, the above definitions present belonging as a feeling of being at home within a spatial or geographical space. Essentially, belonging is rooted in space and justice. Specifically, Yuval-Davis (2011:14) views belonging as about social location that situates every person within a community having emotional attachments to others as an aspect of belonging. Similarly, Wood and Black (2018) assert that belonging is linked to geographic space. Meaning that space and justice serve as the anchor on which the meaning of a sense of belonging is pursuit.

Fundamentally, the definitions bring to the fore a consciousness around one's relationship to a community, and facilitate an individual or collective ability to assess how and why one differs from others. This reiterates the intersectionality of social justice, space and belonging (Alderman and Inwood, 2013). Through this point, Alderman and Inwood (2013: 212) emphasise that "spatial justice stresses the spatiality of belonging, recognising that social (in)justice does not simply have geographical outcomes, rather space plays a more fundamental role in constructing and restructuring the broader processes equality". Consequently, this paper agrees with Antonsich (2010) that belonging in the city is a socially facilitated matter that relates largely to the discourses of and practices of political socio-spatial inclusion and exclusion.

In addition, the aspects of connectedness and relatedness as articulated in the above definition highlight belonging as being more than just being a symbolic, legal and physically location in a spatial jurisdiction. Thus, Antonsich (2010) argues that belonging is about feelings felt, observed and experienced in a specific space. When it is only space without place, belonging become just meaningless inclusion that lacks connectedness and relatedness with the people in a space. In support, (Dijst, 2014) articulates this point succinctly when stating that Living in cities goes further than just having a place of residence. It is also accompanied by increasing exposure to fragmented, temporary, messy, but sometimes intense fluid contacts with unfamiliar people, animate and inanimate entities in public life" 
Fundamentally, a sense of belonging is also socially constructed. Savage (2005:12) argues that a sense of belonging is "an embedded process in which people reflexively judge the suitability of a given space as appropriate given their social trajectory and their position in other fields. Thus, a sense of belonging is not a natural process but rather results from a recognition and affirmation of citizen's identity and ability to participate in the activities of their community. In particular, belonging as place-belongingness adds underlying dynamics. Antonsich (2010) describes place-belongingness as the emotional feeling attached by individuals to a particular place". Antonsich (2010: 6) cautions that place-belongingness is about "humanist geography that offers symbolic space of familiarity, comfort, security and emotional desire for attachment" and not just a physical and material space that reproduce isolation and fear. The humanistic geography that generates place belonging can be conceptualised at multiple scale such as, one's own house, the community, society and the country (Antonsich, 2010). In this regard, placebelongingness transcends the self to include more broadly the collectivities, social ties and relations (YuvalDavids, 2006).

Belonging has social benefits. It elevates social relations, recognition and attachment, which individually and collectively assist in developing a view of oneself to space and others and having the ability to claim or resist exclusion (United Nations, 2007). In addition, belonging is linked to social cohesion. It is intended to promote multiculturalism, trust in others, and trust in institutions, participation, expectations for the future, values and shared norms (United Nations, 2007). According to Holmes (2015), belonging facilitates social connections, solidarity and affiliation. In this regard, belonging ensures that individuals and groups are socially recognised, accommodated and has equal access to social spaces in that geographical places.

Belonging in the context of South Africa, is a constitutional imperative. In particular, the Preamble of the Constitution provides that the Republic of South Africa is one and belongs to all who live in it, united in our diversity. In addition, the pursuit of belonging is regarded as part of Ubuntu. In the highly celebrated Constitutional Court Judgement between State and Makwanyane (1995 para 307), ubuntu: generally, translates as humaneness. In its most fundamental sense, it translates as personhood and morality. Metaphorically, it expresses itself in umntu ngumntu ngabantu, describing the significance of group solidarity on survival issues so central to the survival of communities. While it envelops the key values of group solidarity, compassion, respect, human dignity, conformity to basic norms and collective unity, in its fundamental sense it denotes humanity and morality. Its spirit emphasises respect for human dignity, marking a shift from confrontation to conciliation. In South Africa ubuntu has become a notion with particular resonance in the building of a democracy. It is part of our "rainbow" heritage, though it might have operated and still operates differently in diverse community settings

Belonging is widely recognised as an imperative and a requirement for nation-building. According to the South African Cities Network (2016:127), "all citizens must have a sense of belonging spatially, socio-culturally and economically to our cities and cities were expected enhance this sense of belonging through making and managing spaces and places that people can identify strongly with and frequent freely, without fear of intimidation or being unwelcomed - this is the way of the inclusive city". In addition to the nature, feeling and sense of belonging being envisaged by the Constitution, municipalities are expected to do more than just allocating a house or a piece of land to black people in townships. This is because, just being part of an urban municipality will never be adequate and meaningful without the unjust manifestations being completely removed and justice restored. According to Friedkin (2004), belonging in this context was conceived as the part of social cohesion. It was aimed at facilitating individual and groups to feel as part of, and identify with, the group contributes to the shared values and aspirations underpinned by need for affirmation, friendships and the need to be part of the group (Friedkin, 2004).

Notably, a sense of belonging in South African metros is closely linked to the success of spatial transformation. As indicated in the introduction, it is inconceivable to expect black communities in townships and informal settlements to identify and ultimately have a sense of belonging to municipalities that continue to reflect gross inequality in wealth and service delivery standards. Mogoeng, notes that black people had to endure the centuries-old deprivation of a sense of place and a sense of belonging" (Tshwane Metro vs Afriforum). Importantly, considering that spatial transformation has not yielded anticipated outcomes, it should be accordingly being easy to concede that a sense of belonging on the part of black communities is non-existent. Arguably, a lack of a sense of belonging resulting from spatial injustice has deprived black communities of the right to the city, attachment and social solidarity (Turok \& Scheba, 2018).

The impact of the failure of spatial transformation, is acknowledged by the South African Cities Network (2016: 127) which states that 
"it is time to recognise and respect the contribution of all South Africans to the making of South African cities, in particular how black South Africans can come to legitimise a sense of cultural and economic ownership of cities as producers and not merely consumers or workers". All citizens must have a sense of belonging spatially, socio-culturally and economically to our cities. Cities can begin to express and enhance this sense of belonging through making and managing spaces and places that people can identify strongly with and frequent freely, without fear of intimidation or being unwelcomed".

The failure to archive the spatial transformation simply means that metros have not succeeded in nurturing political and legal space into a place for black communities hence, there experience less or no belonging in these spaces. Understandably, the constitutional aspiration of society based on democratic values, social justice and ensuring that South Africa belongs to all who live in it, united in their diversity has remained unfulfilled. Thus, metros as spaces continue to lack adequate recognition, acceptance and cultural meaning for black communities. Consequently, the lack of diversity, attachment, place identity and social relations have impacted negatively on black communities' sense of belonging to metros.

\section{Possible Effects of Persistent Spatial Injustice on a Sense of belonging in metros}

Earlier sections of this paper has alluded to the failure of metros to transform spatial pattern resulting in perpetuation of spatial injustice. The South African Cities Network (2016: 50) states that the "South African cities are not yet working for all, and certain trends and dynamics are preventing the post-apartheid spatial vision from being achieved". In this regard, the lack of spatial transformation has unavoidably frustrated efforts to realise a sense of belonging, especially by black communities in metros. Following (Gachago, Ivala, Condy, \& Chigona, 2013) assertion that belonging is intricately connected to spatiality, it goes without saying that, spatial injustice will certainly have negative effects on the sense of belonging. Possible effects of spatial injustice on the lack of sense of belonging are identified below.

\section{FRUSTRATION OF DIVERSITY}

A sense of belonging promotes diversity. It is for this reason that Constitution obligates the organs of state to create a just society that will promote recognition, unity and belonging irrespective of differences and diversity. In particular, local government, as an organ of state closest to communities and citizens bears a huge legal and political obligation of creating an environment that promotes a sense belonging for all South Africans.

However, lack of a sense of belonging resulting from spatial injustice has a negative impact on the efforts designed to build a diverse society. Dufaux, Gervais-Lambony, Buire and Desbois (2015) infer that spatial injustice frustrates the ability to promote inclusive and cohesive coalitions among highly diverse groups. The homogenisation and exclusion tendencies inherent in spatial injustice limits belonging to an immediate and same groups but prevents belonging to the broad diverse metro community. Therefore, the nature of connectedness is racial and ethnic based.

\section{Place Detachment}

Attachment as an aspect of a sense belonging promote emotional bond to the space and its people. This bond is not only physical but also emotive and in some instances, spiritual. Rollero and De Piccoli (2010) regard attachment as critical in facilitating the construction of place. In this regard, Rollero and De Piccoli (2010) highlight that attachment makes people feel at home and can improve their well-being. Similarly, Halse (2018) asserts belonging "expresses itself as the sense of attachment or feeling that one fits in and belongs". that Consequently, attachment to the place and people requires regular interactions characterised by acceptance and recognition by others.

Attachment to the metro and its people is possible only when people have a strong sense of belonging to the metro. However, the social distance, alienation, exclusion and displacement caused by spatial injustice result in detachment by black communities from the metro. Inevitably, the lack of attachment to the space and place, impact on the black people's identity and connection to the metros. Thus, it is understandable for black people to continue to reflect attachment to their former homelands.

\section{FraCtURED SOCIAL RELATIONS}

Social relations are an aspect of belonging. It is experienced or observed as feelings generated when individuals or groups interact with others United Nations (2006). It develops through regular interaction facilitated by sharing public spaces. As a feeling of relatedness and connectedness, belonging allows for the establishment of relations 
across the metro. Halse (2018) advises that belonging should promote new socials collective relations that he refers to as creating a society of strangers. These relations assist in the construction of identity, attachments and general well-being.

It is however, impractical to form relations across the metros characterised by isolation and social distance between its inhabitants. Spatial injustice makes social relations impossible. Neely and Samura (2011) explain this view that as reflecting a reality that space manifesting relations of power have the ability limit the social interaction among the people. As a manifestation of power, social relations are formed not share power but to contest power. Therefore, instead of promoting relations among communities and citizens living across the metro, conflict tends to be more prevalent.

In addition, that politicised space such as metros characterised by spatial injustice is certainly highlighly contested and politicised and it tends to create intricate "web of relations of domination and subordination of, solidarity and cooperation" (Neely and Samura (2011: 1936). Therefore, spatial injustice promotes social polarisation more that social interaction. In addition, wide-ranging networks and affiliations will be negative affected by artificial boundaries inherent in spatial injustice. Quite evidently, it is the fact that spatial injustice produces racial antagonism and fractured social relations. In addition, spatial injustice impacts negatively on the ability to facilitate social solidarity, allegiance and belonging.

\section{LiMiTED CiTIZENSHIP}

Belongingness intersect with citizenship. Local citizenship to metros means the ability of individuals to interact with public spaces in a manner that does not compromise their self-identity, let alone obstruct, threaten or even harm them more materially. Citizenship is related to the right to the city or city for all, which pertains to the collective claim for the urban area by all who live in the city.

Notably, the inability to transform the spatial fragmentation has not only exacerbated injustice and inequality in cities, but has also affected negatively on the most vulnerable and marginalised poor to identify and belong to their respective metros. Thus, the involvement of black people in metro processes has remained limited due to untransformed spatial justice. Consequently, black communities cannot claim some metro space and processes.

\section{LACK OF Social CAPITAL}

Social capital is intrinsic in a sense of belonging. Social capital refers to resources of individuals that emerges from their social ties (Putnam, 2000). More broadly, Oxoby (2009:1136), refers to social capital as an "individual's sacrifices (time, effort, and consumption) made in an effort to co-operate with others'. Putnam (2000) further states that social capital is facilitated through connections among individual's social networks and the norms of reciprocity and trustworthiness that arise from them. Importantly, components such as "trust, social networks, norms and reciprocity seem to be prominent in social capital formation" (Cloete, 2014). Certainly, spatial injustice makes it impossible for black communities to access social capital that is available in white communities.

\section{ERosion OF Trust}

Trust is a fundamental element of socially cohesive societies. According to (Smith, 2010) trust is a social lubricant that reduces complexity. Therefore, trust encourages solidarity, cohesion, consensus, cooperation and belonging. Eroding of trust could harm social cohesion in communities and societies in general. Notably, high levels of trust can be a good thing for a cohesive society. Therefore, trust has potential consequences and affecting a sense of belonging.

The lack of trust, reciprocity and networks due to spatial injustice confines social capital in one area and not others. Thus, the untransformed spatiality perpetuate what is referred to as particularised trust for both black and white communities. Particularised trust according to (Uslaner, 2011) are those individuals who are particularised trusters that have faith only in those from their own, or a very similar background. Accordingly, relationships are formed around only those in the immediate community (Kearns \& Forrest, 2000). Notably, their relative isolation from the wider society negatively influence their sense of belonging

\section{CONCLUSION}

The question being pursuit in this paper was what are the possible effects of spatial injustice on black communities' sense of belonging in urban municipalities. After discussing the concept of spatial justice and the challenged relating the South Africa untransformed spatial patterns, the paper listed frustration of diversity; lack of place attachment; fractured social relations; limited citizenship, lack of social capital and erosion of trust as key effects 
of spatial injustice on the sense of belonging. Therefore, the Metros have an obligation to promote sense of belonging for all its citizens in order to achieve social cohesion.

\section{REFERENCES}

Charman, A., Tonkin, C., Denoon-stevens, S., \& Demeestére, R. (2017). Post-Aparthied Spatial Inequality : Obstacles of Land Use Management on Township Micro-Enterprise Formalisation. A Report by the Sustainable Livelihoods Foundation, (August).

City of Tshwane Metropolitan Municipality v Afriforum and Another. (2016). (157/15) [2016] ZACC 19; 2016 (9) BCLR 1133 (CC); 2016 (6) SA 279 (CC) (21 July 2016).

Cloete, A. (2014). Social cohesion and social capital: Possible implications for the common good. Verbum et Ecclesia. https://doi.org/10.4102/ve.v35i3.1331.

Dijst, M. (2014). Social connectedness: a growing challenge for sustainable cities. Asian Geographer, 31(2), 175-182. https://doi.org/10.1080/10225706.2014.942947.

Dikeç, M. (2001). Justice and the spatial imagination. Environment and Planning A, 33(10), 1785-1805. https://doi.org/10.1068/a3467.

Friedkin, N.E. (2004) Social Cohesion. Annual Review of Sociology, 30, 409-425. https://doi.org/10.1146/annurev.soc.30.012703.110625.

Fuo, O. (2013). Local government indigent policies in the pursuit of social justice in South Africa through the lenses of Fraser. Stell Lr, (2014), 187-208.

Gachago, D., Ivala, E., Condy, J., \& Chigona, A. (2013). Journeys Across Difference: Pre-service Teacher Education Students' Perceptions of a Pedagogy of Discomfort in a Digital Storytelling Project in South Africa. Critical Studies in Teach and Learning, 1(1), 22-52. https://doi.org/10.14426/cristal.v1i1.4.

Halse, C. (2018). Interrogating Belonging for Young People in Schools. London: Palgrave.

Hill, D. L. (2006). Sense of Belonging as Connectedness, American Indian Worldview, and Mental Health. Archives of Psychiatric Nursing, 20(5): 210-216.

Holmes, C. E. (2015). United in Diversity or Divided in Difference: Belonging and Opposition in Democratic South Africa. Southern African Peace and Security Studies, 1(2): 4-19.

Hooks, B. (2009). Belonging: A Culture of Place. New York: Routledge.

Hopkins, N and Dixon, J. (2006). Space, Place, and Identity: Issues for Political Psychology Author(s): Source: Political Psychology, Vol. 27(2): 173-185

Israel, E., \& Frenkel, A. (2018). Social justice and spatial inequality: Toward a conceptual framework. Progress in Human Geography, 42(5), 647-665. https://doi.org/10.1177/0309132517702969.

Kamenov, Z. (2003). National Identity and Spatial Distance: Does In-Group Loyalty Lead to Outgroup Hostility. Review of Psychology, 10(2): 85-94.

Kearns, A., \& Forrest, R. (2000). Social cohesion and multilevel urban governance. Urban Studies, 37(5-6), 995-1017. https://doi.org/10.1080/00420980050011208.

Kitchin, R. (1998). "Out of place", "knowing one's place": Space, power and the exclusion of disabled people. Disability and Society, 13(3), 343-356. https://doi.org/10.1080/09687599826678.

Langa, P. (2006). Transformative Constitutionalism. Stell Law Review, 351-360.

Manzo, L.C. (2003). Beyond House and Haven: Toward a Revisioning of Emotional Relationships with Places. Journal of Environmental Psychology, 23(1): 47-61

Neely, B. \& Samura, M. (2011) Social geographies of race: connecting race and space, Ethnic and Racial Studies, 34:11, 1933-1952, DOI: 10.1080/01419870.2011.559262.

Oxoby, R. (2009). Understanding social inclusion, social cohesion, and social capital. International Journal of Social Economics, 36(12), 1133-1152. https://doi.org/10.1108/03068290910996963. 
Pieterse, E. (2019). Urban governance and spatial transformation ambitions in Johannesburg. Journal of Urban Affairs, 41(1), 20-38. https://doi.org/10.1080/07352166.2017.1305807

Putnam, R. D. (2000). Bowling Alone: The Collapse and Revival of American Community. New York; London: Simon \& Schuster.

Rollero, C. and De Piccoli, N. (2010). Place Attachment, Identification and Environment Perception: An empirical Study. Journal of Environmental Psychology, 30, 198-205.

Saar, M., \& Palang, H. (2009). The dimensions of place meanings. Living Reviews in Landscape Research, 3, 1-24. https://doi.org/10.12942/lrlr-2009-3.

SALGA. (2016). SALGA: Strategic Framework 2017 - 2022: National Strategic Conference Discussion Papers 28 November - 01 December 2016, 1-48. Retrieved from http://salga.org.za/nc/docs/3._SALGA_Draft_Strategic_Framework_20172022.pdf.

Smith, S. S. (2010). Race and Trust. Annual Review of Sociology, 36(1), 453-475. https://doi.org/10.1146/annurev.soc.012809.102526.

Soja, E.W.(1980). The Socio-Spatial Dialectic Annals of the Association of American Geographers, 70(2): 207-225.

South African Cities Network; Johannesburg Development Agency. (2014). Spatial Transformation of Cities: Conference Report.

Turok, I. (2016). South Africa, s new urban agenda: Transformation or compensation? https://doi.org/10.1177/0269094215614259

Turok, I., \& Scheba, A. (2018). 'Right to the city' and the New Urban Agenda: learning from the right to housing. Territory, Politics, Governance, O(0), 1-17. https://doi.org/10.1080/21622671.2018.1499549.

United Nations. (2017). Social Cohesion: Inclusion and a Sense of Belonging in Latin America and the Caribbean. Santiago: United Nations.

United Nations Human Settlements Programme, (2006). The State of the World's Cities Report 2006/7: The Millennium Development Goals and Urban Sustainability: 30 Years of Shaping the Habitat Agenda. Nairobi: Habitat.

Usmani, S. (2013). Impact of Distributive Justice, Procedural Justice, Interactional Justice, Temporal Justice, Spatial Justice on Job Satisfaction of Banking Employees. Rev. Integr. Bus. Econ. Res, 2(1): 351-383.

Uslaner, E. M. (2011). The Moral Foundations of Trust. SSRN Electronic Journal, (October). https://doi.org/10.2139/ssrn.824504.

Visser, G. (2001). Social Justice , Integrated Development Planning and Post- apartheid Urban Reconstruction, 38(10), 16731699.

Withers, C. W. J. (2009). Place and the "spatial turn" in geography and in history. Journal of the History of Ideas, 70(4), 637658. https://doi.org/10.1353/jhi.0.0054.

Wood, B. E. and Black, R. (2018). Spatial, Relational and Affective Understandings of Citizenship and belonging for Young People Today: Towards a new Conceptual Framework. [Online] Available at: http://dro.deakin.edu.au/view/DU:30111085 [Accessed on 12 September 2019].

Yuval-davis, N. (2015). Power, Intersectionality and the Politics of Belonging Power, Intersectionality and the Politics of Belonging Nira Yuval-Davis FREIA Working Paper Series, (January 2011). https://doi.org/10.5278/freia.58024502. 